\title{
IMPLEMENTASI GRAPHQL UNTUK MENGATASI UNDER- FETCHING PADA PENGEMBANGAN SISTEM INFORMASI PELACAKAN ALUMNI POLITEKNIK NEGERI MALANG
}

\author{
Annisa Taufika Firdausi', Dhebys Suryani Hormansyah², Fany Ervansyah ${ }^{3}$ \\ 1,2,3 Program Studi Teknik Informatika, Jurusan Teknologi Informasi, Politeknik Negeri Malang \\ 12annisa.taufika@polinema.ac.id, ${ }^{2}$ dhebys.suryani@polinema.ac.id, ${ }^{3}$ fanyervansyah.9c@ gmail.com
}

\begin{abstract}
Abstrak
Pendistribusian data pada sistem informasi memiliki berbagai macam cara yang digunakan. Diantaranya adalah dengan menggunakan metode REST API. Namun, terdapat beberapa kekurangan yang menjadi masalah pada REST API.Salah satunya adalah masalah under-fetching, yaitu masalah dimana bagian frontend harus melakukan lebih dari satu kali request ke backend untuk memenuhi kebutuhan data yang diperlukan oleh frontend. Tentunya under-fetching ini dapat menurunkan performa sistem yang dibuat. Salah satu cara untuk mengatasi underfetching dapat dilakukan dengan menerapkan GraphQL sebagai metode pendistribusian data. Tujuan dari penelitian kali ini adalah untuk membandingkan performa antara sistem informasi dengan REST API dan sistem informasi dengan GraphQL. Studi kasus pada penelitian ini adalah pada pengembangan sistem informasi pelacakan alumni Politeknik Negeri Malang dimana dibuat dua versi sistem informasi yang metode pendistribusian data REST dan menggunakan GraphQL.Hasil penelitian ini berupa perbandingan performa antara sistem informasi dengan metode pendistribusian data REST API dan sistem informasi dengan metode pendistribusian data GraphQL. Berdasarkan hasil percobaan yang dilakukan GraphQL menunjukkan performa yang baik pada jumlah data yang besar dan kompleks, serta ketika terdapat banyak pengguna yang mengakses data dalam waktu yang bersamaan. Sedangkan untuk data yang sederhana dan sistem informasi yang tidak memiliki banyak pengguna yang akan mengakses data secara bersamaan, maka REST API masih lebih unggul.
\end{abstract}

Kata kunci : Sistem Informasi, GraphQL, under-fetching

\section{Pendahuluan}

Distribusi data merupakan hal yang sangat penting dalam pengembangan sebuah sistem informasi. Dalam pendistribusian data, beberapa website menerapkan metode yang berbeda-beda. Mulai dari menggabungkan antara bagian yang bertugas menampilkan informasi ke pengguna (Frontend) dan bagian yang mengatur bagaimana data diolah (Backend) hingga menyediakan layanan distribusi data seperti REST API, untuk sistem dengan struktur frontend dan backend yang terpisah.

REST API adalah salah satu teknik yang populer karena merupakan sebuah teknik yang tidak tergantung pada protokol spesifik, dapat menggunakan HTTP dan menggunakan format JSON untuk berkomunikasi (Doglio, 2018). Namun, dalam metode REST API, terdapat suatu masalah yang disebut under-fetching, dimana bagian frontend perlu untuk melakukan permintaan data lebih dari 1 kali ke bagian backend (Porcello \& Banks, 2018). Hal itu akan meningkatkan latensi, yang membuat pengakses halaman web harus menunggu lebih lama sebelum data dikirim pada bagian frontend dengan sempurna. Selain itu, kompleksitas program juga semakin bertambah karena bagian frontend harus menambahkan satu permintaan data lagi ke bagian backend.

Salah satu cara mengatasi under-fetching pada REST API adalah dengan membuat endpoint baru yang melakukan pengambilan data sesuai dengan apa yang diminta oleh frontend. Namun, jika terdapat banyak data yang mirip dan memiliki endpoint masing-masing, maka bentuk kode pada bagian backend akan menjadi kompleks dan kurang baik diakibatkan oleh adanya kode yang memiliki fungsi mirip namun ditulis lebih dari 1 kali.

Pada tahun 2015, secara publik, Facebook meluncurkan sebuah query language yang menjadi metode baru dalam mengatur pendistribusian data. Nama query language tersebut adalah GraphQL. Salah satu masalah yang dapat diatasi oleh GraphQL adalah masalah under-fetching.

Banyak penelitian sebelumnya yang membahas mengenai pemanfaatan GraphQL dalam menyelesaikan masalah under-fetching, antara lain dilakukan oleh (Hartig \& Pérez, 2017), pada penelitian tersebut disimpulkan bahwa bahasa Graph milik GraphQL memiliki kompleksitas yang rendah, selanjutnya ada juga penelitian yang membandingkan antara REST dan GraphQL yang dilaksanakan oleh (Eizinger, 2017). 
Penelitian lain memanfaatkan GraphQL dalam riset mengenai kemampuan GraphQL dalam berkomunikasi dan bertukar data pada ekosistem yang menggunakan teknologi data driven, pada penelitian tersebut disimpulkan bahwa GraphQL menunjukkan peningkatan dalam fleksibelitas, maintainabilitas dan performa (Vazquez-Ingelmo, Cruz-Benito, \& García-Penalvo, 2017).

Peneliti lain juga membahas mengenai performa pengambilan data yang mengkombinasikan antara Falcor dan Relay + GraphQL para penelitian tersebut masih belum dapat menentukan mana yang memberikan latency yang lebih rendah antara Relay + GraphQL atau REST API namun berhasil menemukan bahwa Falcor dan Relay+GraphQL dapat menurunkan jumlah request untuk data flow yang paralel dan sekuensial untuk single request (Cederlund, 2016).

GraphQL juga dapat dimanfaatkan sebagai content delivery pada Kentico Cloud, ada penelitian yang mencoba mengganti content delivery dari REST API ke GraphQL pada sebuah CMS online, penelitian tersebut menyimpulkan bahwa GraphQL dapat digunakan sebagai pengganti REST API namun tidak terdapat perbedaan signifikan untuk penurunan data flow pada jaringan antara Graph $Q L$ dan REST API (Čechák, 2017).

Penelitian lain membahas mengenai perbandingan performa antara GraphQL dan REST API pada sistem informasi, penelitian tersebut menyimpulkan bahwa GraphQL dapat menjadi pilihan yang tepat ketika data yang dibutuhkan sering berubah (Hartina, Lawi, \& Panggabean, 2018).

Mengkombinasikan antara GraphQL dengan teknologi lain juga menjadi topik yang sering diteliti antara lain (Mukhiya, Rabbiab, Punax, Rutle, \& Lamo, 2019) dimana pada penelitian tersebut dilakukan evaluasi proses pertukaran informasi pada sebuah healthcare system menggunakan kombinasi GraphQL dan HL7 FHIR.

Penelitian mengenai kemampuan GraphQL dalam melakukan query data menyimpulkan bahwa GraphQL dapat melakukan query dengan efektif sesuai situasi dan tidak mengirimkan data yang tidak berlebihan jika dibandingkan dengan REST API (Jeon, Liuhaoyang, \& Hwang, 2019). Sampai sekarang evaluasi dan perbandingan kemampuan antara GraphQL dan REST API masih terus menjadi topik yang menarik untuk diteliti (Brito \& Valente, 2020) melakukan eksperimen membandingan GraphQL dan REST API, (Lee, Kwon, \& Yun, 2020) mengukur performa GraphQL pada ESS (Energy Storage System) dan yang terbaru (Vadlamani, Emdon, Arts, \& Baysal, 2021) meneliti apakah GraphQL dapat menggantikan REST API.

Pada penelitian ini akan dilakukan evaluasi implementasi GraphQL untuk mengatasi underfetching pada Pengembangan Sistem Informasi Pelacakan Alumni Politeknik Negeri Malang yang akan penulis kembangkan. Dengan adanya Graph $Q L$, diharapkan dapat meningkatkan performa situs web Sistem Informasi Pelacakan Alumni Politeknik Negeri Malang.

\section{Tinjauan Pustaka}

\subsection{Underfetching}

Under-fetching menjadi masalah pada suatu sistem informasi karena memiliki dampak pada penurunan performa suatu situs web. Penurunan performa tersebut terjadi dikarenakan adanya proses 'meminta kembali suatu data pada backend di endpoint yang berbeda. Hal ini menyebabkan adanya tambahan aktivitas pada sistem. Secara teori, hal itulah yang menyebabkan performa sistem informasi menjadi terhambat.

Sebagai contoh, jika dalam suatu sistem terdapat halaman yang melakukan request ke 2 endpoint yang berbeda, misalnya /user/id untuk mendapatkan data pengguna dan /users/id/items untuk mendapatkan data barang yang dimiliki pengguna, maka sistem memiliki 2 aktivitas yang harus dilakukan, yaitu meminta data pada endpoint lusers, sekaligus meminta data pada endpoint lusers/items.

Masalah ini dapat diatasi dengan cara menggabungkan 2 data yang berbeda tersebut menjadi 1 endpoint saja. Namun, hal ini juga memiliki kekurangan dimana jika sistem hanya akan menggunakan data diri pengguna saja, sistem juga akan menerima data item pengguna yang tidak diperlukan. Sehingga, terjadilah pengambilan data yang berlebihan.

Masalah inilah yang diselesaikan oleh GraphQL. GraphQL membantu sistem untuk menentukan data apa yang harus diambil berdasarkan query yang tersedia dari backend. Backend menentukan data apasaja yang boleh diambil, dan bagian frontend juga bisa menentukan data apa saja yang bisa diambil sesuai dengan apa yang disediakan oleh backend.

Misalnya, terdapat data pengguna yang terdiri dari name, email, role, dan password. Bagian backend menyediakan query untuk mengambil data pengguna yang berupa name, email, dan role. Maka, bagian frontend dapat mengambil data dari query tersebut, entah mengambil name saja, name dan email saja, dan sebagainya. Namun, bagian frontend tidak akan bisa mengambil password karena query tidak disediakan oleh backend.

GraphQL juga dapat mengambil data dari beberapa query sekaligus. Misalkan terdapat query user dan item, maka bagian frontend dapat melakukan pengambilan data user dan data item dalam 1 kali request. Hal inilah yang menjadikan GraphQL mampu untuk menyelesaikan masalah under-fetching. 


\section{Metode Penelitian}

Penelitian dibagi menjadi tiga tahapan besar yaitu tahap pengambilan data, tahap pengembangan sistem dan tahap pengujian.

\subsection{Metode Pengambilan Data}

Pengambilan data dilakukan dengan cara scraping pada situs Linkedin dan input secara manual melalui sistem informasi yang akan dibuat.

Pada pengambilan data di Linkedin, data yang diambil adalah data mahasiswa yang sudah mendaftarkan Politeknik Negeri Malang sebagai riwayat pendidikan mereka. Mekanisme pengambilan datanya adalah dengan menggunakan bot untuk melakukan login terotomatisasi, kemudian masuk ke halaman Politeknik Negeri Malang, lalu membuka halaman detail setiap card dari mahasiswa yang muncul. Dari halaman detail yang sudah dibuka, akan diambil data-data yang diperlukan.

Pada pengambilan data dari input manual, pengambilan data dilakukan dengan mengisikan data alumni melalui form yang sudah disediakan di sistem. Form tersebut memiliki field diantaranya berupa nama, tahun masuk dan lulus dari Politeknik Negeri Malang, jurusan yang diambil, pekerjaan saat ini, jabatan/posisi yang dipegang pada pekerjaan saat ini, dan email.

\subsection{Metode Pengembangan Sistem}

Metode pengembangan aplikasi yang penulis gunakan adalah metode Agile dengan framework Kanban. Alasan penulis memilih metode Kanban karena metode ini memiliki WIP (Work-In-Progress) yang memberi batasan berapa banyak tugas yang bisa diselesaikan (Kniberg \& Skarin, 2010). Sehingga, pengembang dapat fokus pada beberapa tugas terlebih dahulu. Untuk teknologi pada bagian frontend, pennulis akan menggunakan React.js, yaitu sebuah library untuk mengembangkan bagian frontend dari suatu web (Alex \& Eve, 2017). Untuk backend, penulis akan menggunakan Node.js karena Node.js mampu membuat server-side program dengan menggunakan bahasa javascript (Brown, 2014).

\subsection{Metode Pengujian}

Setup pengujian di lakukan pada website sistem informasi alumni yang sudah dipublish ke sebuah virtual private server. Sistem informasi alumni ini terdapat dua versi yaitu versi yang memanfaatkan GraphQL dan yang menggunakan REST API.

Pengujian pertama akan dilakukan dengan cara memuat suatu halaman yang sama dan memiliki masalah under-fetching, pada Sistem Informasi yang menggunakan GraphQL maupun yang menggunakan REST sebagai metode pendistribusian datanya. Kemudian, halaman akan di-refresh sebanyak 20 kali. Pada masing-masing sesi refresh, akan ada beberapa data yang dicatat pada masingmasing sistem informasi. Diantaranya adalah jumlah request ke backend, waktu muat request hingga selesai, dan waktu total memuat halaman. Dari datadata tersebut, akan dirata-rata pada masing-masing sistem informasi dan akan dibandingkan. Sehingga, dapat diketahui kelebihan/kekurangan dari GraphQL dan REST jika digunakan dalam pendistribusian data.

Uji coba kedua adalah dengan menggunakan bantuan tool bernama K6, yaitu tool untuk melakukan berbagai macam load testing. Penulis akan menguji kemampuan backend dari masingmasing metode pendistribusian data dalam menangani jumlah user yang melakukan permintaan data secara bersamaan. Jumlah user yang disimulasikan sejumlah 50 users dan batas durasi yang diberikan adalah 1 menit. Sehingga, 50 users akan melakukan request secara bersamaan dan selama 1 menit, akan dicatat berapa user yang mendapatkan respon dari backend.

GraphQL dikatakan berhasil menyelesaikan masalah under-fetching jika sistem yang dikembangkan dengan mengimplementasikan GraphQL dapat melakukan pengaksesan endpoint lebih sedikit daripada sistem dengan metode REST $A P I$ dalam memenuhi kebutuhan datanya atau jika server dengan GraphQL dapat merespon sejumlah user yang lebih banyak dibandingkan dengan REST API.

\section{Hasil dan Pembahasan}

\subsection{Hasil Uji Muat Halaman Dashboard}

Tabel 1 Hasil Uji Muat Halaman Dashboard

\begin{tabular}{|l|c|c|}
\hline \multicolumn{1}{|c|}{ Metode } & $\begin{array}{c}\text { Jumlah Request } \\
\text { ke backend }\end{array}$ & $\begin{array}{c}\text { Kecepatan } \\
\text { rata-rata }\end{array}$ \\
\hline REST API & 5 & $623 \mathrm{~ms}$ \\
\hline GraphQL & 1 & $635,7 \mathrm{~ms}$ \\
\hline
\end{tabular}

Pada halaman dashboard di sistem informasi dengan REST, terjadi 5 kali request dengan data yang sederhana, yaitu berupa total dari beberapa kategori data, dan ditampilkan sekaligus.

Hasil akhir uji muat halaman dashboard menunjukkan bahwa GraphQL berhasil mengatasi masalah under-fetching dengan hanya memerlukan 1 endpoint saja untuk memenuhi semua kebutuhan datanya. Sedangkan REST membutuhkan 5 kali request ke backend untuk memenuhi kebutuhan datanya. Namun, kecepatan muat halaman pada sistem informasi dengan REST masih lebih cepat dibandingkan sistem informasi dengan GraphQL. Selisih waktu dari masing-masing rata-rata kecepatan muat halaman adalah 12,7 milisekon dengan sistem informasi yang REST lebih unggul. 
Dari hasil tersebut, terlihat bahwa GraphQL dapat mengatasi masalah under-fetching. Namun, untuk kasus data yang sederhana, kasus underfetching tidak memberikan dampak yang mempengaruhi performa. Sehingga, REST API masih lebih cepat dibandingkan GraphQL dalam pemuatan data untuk ditampilkan pada halaman yang dimaksud.

\subsection{Hasil Uji Muat Halaman List Alumni}

Tabel 2 Hasil Uji Muat Halaman List Alumni

\begin{tabular}{|c|c|c|}
\hline Metode & $\begin{array}{c}\text { Jumlah Request } \\
\text { ke backend }\end{array}$ & $\begin{array}{c}\text { Kecepatan } \\
\text { rata-rata }\end{array}$ \\
\hline REST API & 2 & $1.398 \mathrm{~ms}$ \\
\hline GraphQL & 1 & $944,5 \mathrm{~ms}$ \\
\hline
\end{tabular}

Pada halaman list alumni, terdapat masalah under-fetching pada sistem informasi dengan REST. Dimana, sistem harus melakukan 2 kali request ke backend untuk memenuhi kebutuhan yang berupa data beberapa alumni dengan sumber yang berbeda, pengaturan halaman, total halaman dan total data yang didapat sekaligus. Hal ini menunjukkan bahwa pada halaman list alumni, terdapat data yang lebih kompleks dan besar dibanding pada halaman dashboard, namun dengan kasus under-fetching tidak sebesar pada halaman dashboard karena hanya terdapat 2 kali request ke backend.

Hasil uji coba muat halaman list alumni menunjukkan bahwa GraphQL berhas il mengatasi masalah under-fetching dengan hanya melakukan 1 kali request ke backend untuk memenuhi kebutuhan datanya. Sedangkan sistem informasi dengan REST membutuhkan 2 kali request ke bagian backend untuk memenuhi kebutuhan data yang akan ditampilkan. Perbandingan rata-rata kecepatan muat halaman pada masing-masing sistem menunjukkan bahwa GraphQL lebih cepat dibandingkan dengan REST API. Selisih dari rata-rata kecepatan muat halaman dari masing-masing sistem informasi adalah 453,5 milisekon dengan dengan GraphQL yang lebih unggul.

Dari hasil tersebut, dapat dilihat bahwa, untuk data yang besar dan lebih kompleks dibandingkan dengan halaman dashboard, kasus under-fetching mulai memberikan dampak pada performa suatu halaman web dan GraphQL mampu mengatasi masalah tersebut sekaligus meningkatkan performa suatu halaman web. Sehingga, waktu muat halaman web pada sistem informasi dengan GraphQL dapat lebih singkat dibandingkan dengan waktu muat halaman web dengan REST API.

\subsection{Hasil Uji Muat Halaman Edit Alumni}

Tabel 3 Hasil Uji Muat Halaman Edit Alumni

\begin{tabular}{|c|c|c|}
\hline Metode & $\begin{array}{c}\text { Jumlah Request } \\
\text { ke backend }\end{array}$ & $\begin{array}{c}\text { Kecepatan } \\
\text { rata-rata }\end{array}$ \\
\hline REST API & 2 & $738,85 \mathrm{~ms}$ \\
\hline
\end{tabular}

\begin{tabular}{|c|c|c|}
\hline Metode & $\begin{array}{c}\text { Jumlah Request } \\
\text { ke backend }\end{array}$ & $\begin{array}{c}\text { Kecepatan } \\
\text { rata-rata }\end{array}$ \\
\hline GraphQL & 1 & $779,7 \mathrm{~ms}$ \\
\hline
\end{tabular}

Pada halaman ini, terdapat kasus underfetching dimana sistem informasi dengan REST melakukan 2 kali request dengan data yang tidak terlalu besar dibandingkan dengan halaman list alumni, yaitu meminta detail dari data alumni yang akan diubah dan meminta list jurusan yang sudah terdaftar pada sistem. Artinya, pada halaman edit alumni ini terdapat kasus under-fetching yang sama dengan halamn list alumni, yaitu 2 kali request, namun datanya tidak sebesar data pada halaman list alumni.

Hasil uji muat halaman edit alumni menunjukkan bahwa GraphQL dapat mengatasi masalah under-fetching dengan hanya membutuhkan 1 kali request saja ke backend untuk memenuhi data yang diperlukan. Sedangkan sistem informasi dengan REST API membutuhkan 2 kali request untuk memenuhi kebutuhan data yang akan ditampilkan. Selisih rata-rata waktu muat halaman pada sistem informasi dengan REST API dan sistem informasi dengan GraphQL adalah 40,85 milisekon dengan REST API lebih unggul dibandingkan GraphQL.

Dari data tersebut, dapat dilihat bahwa untuk kasus data yang lebih kecil dibandingkan pada halaman list alumni dengan jumlah request yang sama, yaitu 2 kali requests, kasus under-fetching tidak memberikan pengaruh yang besar pada performa halaman web, namun lebih memberikan pengaruh pada efisiensi penggunaan kuota data internet. Sehingga, meskipun kasus under-fetching dapat diatasi, kecepatan muat halaman pada sistem informasi dengan GraphQL masih sedikit lebih lambat dibandingkan dengan sistem informasi dengan REST API.

\subsection{Hasil Load Testing Endpoint Halaman Dashboard.}

Tabel 4 Hasil Load Testing Halaman Dashboard

\begin{tabular}{|l|c|c|c|c|}
\hline Metode & $\begin{array}{c}\text { Ite } \\
\text { ras } \\
\mathbf{i}\end{array}$ & $\begin{array}{c}\text { Kecepata } \\
\text { n rata- } \\
\text { rata/iter } \\
\text { asi (s) }\end{array}$ & $\begin{array}{c}\text { Total } \\
\text { data } \\
\text { dikirim } \\
(\mathbf{B})\end{array}$ & $\begin{array}{c}\text { Total } \\
\text { data } \\
\text { diterima } \\
(\mathbf{B})\end{array}$ \\
\hline REST API & 151 & 16 & 361524 & 1012434 \\
\hline GraphQL & 156 & 16 & 108636 & 222666 \\
\hline
\end{tabular}

Hasil load testing endpoint halaman dashboard pada sistem informasi dengan REST dan GraphQL terdiri dari beberapa kategori dengan perlakuan yang sama pada masing-masing sistem. Dilakukan permintaan ke backend oleh 50 user. Ketika 1 user telah menyelesaikan request data yang dibutuhkan dan mendapatkan respon dari backend, user akan segera melakukan request kembali ke 
backend. Perlakuan ini akan terulang secara terusmenerus selama 1 menit.

Hasil dari uji coba pada backend dengan REST API menunjukkan bahwa terjadi 151 iterasi permintaan dari 50 user dengan jumlah request sebanyak 755 dan semua permintaan berhasil mendapatkan respon sukses dari backend. Rata-rata waktu yang dibutuhkan untuk masing-masing iterasi adalah 16 detik dengan waktu maksimal 21 detik dan waktu minimal 4 detik.

Hasil dari load testing backend dengan GraphQL menunjukkan bahwa terjadi 156 iterasi pengguna dengan jumlah request sebanyak 156 kali dan semua iterasi mendapatkan respon sukses dari backend. Rata-rata waktu yang dibutuhkan untuk setiap iterasi adalah 16 detik dengan waktu maksimal 20 detik dan waktu minimal 2 detik.

Dari segi eifisiensi penggunakan kuota internet, jumlah data yang diterima pada sistem informasi dengan REST API adalah 1012434 bytes dan jumlah data yang dikirimkan adalah 361524 bytes. Pada sistem informasi dengan GraphQL, data yang diterima adalah 222666 bytes dan data jumlah data yang dikirmkan adalah 108636 bytes.

Dari percobaan tersebut, dapat dilihat bahwa GraphQL lebih mampu dalam memberikan respon ke user dengan jumlah respon sebanyak 156 kali. Jumlah ini lebih banyak 5 iterasi dibandingkan dengan respon yang berhasil diberikan oleh backend dengan REST API. Untuk kecepatan respon, backend dengan GraphQL mapun backend dengan REST API memiliki rata-rata kecepatan yang sama. Dari segi efisiensi kuota data internet, dapat dilihat bahwa GraphQL mengirimkan dan menerima data lebih efisien dari REST API. Hal ini terjadi karena pada masing-masing request di sistem informasi dengan REST, terjadi validasi token dan token yang sama dikirimkan berkali-kali ke backend. Karena mengakses banyak endpoint, maka sistem informasi dengan REST menerima berbagai data dengan tambahan header data pada masing-masing respon. Sedangkan pada GraphQL, karena hanya terjadi 1 kali request, maka token hanya dikirmkan sekali dan juga mendapatkan keseluruhan data dalam 1 respon.

\subsection{Hasil Load Testing Endpoint Halaman List Alumni.}

Hasil load testing endpoint halaman list alumni pada sistem informasi dengan REST dan GraphQL terdiri dari beberapa kategori dengan perlakuan yang sama pada uji coba sebelumnya. Dilakukan permintaan ke backend oleh 50 user. Ketika 1 user telah menyelesaikan request data yang dibutuhkan dan mendapatkan respon dari backend, user akan segera melakukan request kembali ke backend. Perlakuan ini akan terulang selama 1 menit.
Tabel 5 Hasil Load Testing Halaman List Alumni

\begin{tabular}{|l|c|c|c|c|}
\hline $\begin{array}{l}\text { Meto } \\
\text { de }\end{array}$ & Iterasi & $\begin{array}{c}\text { Kecepatan } \\
\text { rata- } \\
\text { rata/iterasi } \\
\text { (s) }\end{array}$ & $\begin{array}{c}\text { Total } \\
\text { data } \\
\text { dikirim } \\
\text { (B) }\end{array}$ & $\begin{array}{c}\text { Total } \\
\text { data } \\
\text { diterima } \\
(\mathbf{B})\end{array}$ \\
\hline $\begin{array}{l}\text { REST } \\
\text { API }\end{array}$ & 291 & 9,5 & 232650 & 5220098 \\
\hline $\begin{array}{l}\text { Graph } \\
\text { QL }\end{array}$ & 309 & 8,9 & 321321 & 4263453 \\
\hline
\end{tabular}

Hasil dari percobaan pada backend dengan REST menunjukkan bahwa terjadi 291 iterasi permintaan dari 50 user dengan jumlah request sebanyak 602 request, dengan 582 request berhasil mendapatkan respon sukses dari backend, sedangkan sisanya masih belum selesai diproses. Rata-rata durasi waktu yang dibutuhkan untuk masing-masing iterasi adalah 9,5 detik dengan waktu maksimal 13,7 detik dan waktu tersingkat 7 detik.

Pada backend dengan GraphQL, terjadi 309 iterasi permintaan dari 50 user dengan jumlah request 309 kali serta keseluruhannya mendapat respon sukses dari backend. Rata-rata durasi waktu yang diperlukan untuk masing-masing iterasi adalah 8,9 detik dengan waktu maksimal 17,8 detik dan waktu minimal 1,7 detik.

Dari segi efisiensi kuota internet, jumlah data yang diterima pada sistem informasi dengan REST adalah 5220098 bytes dan data yang dikirimkan adalah 232650 bytes. Sedangkan pada sistem informasi dengan GraphQL, data yang diterima adalah 4263453 bytes dan data yang dikirimkan adalah 321321 bytes.

Dari hasil di atas, dapat dilihat bahwa GraphQL mampu menangani jumlah user yang lebih banyak dibanding dengan REST API di mana GraphQL mampu merespon hingga iterasi ke 309, sedangkan REST mampu merespon request hingga iterasi ke-291. untuk durasi respon, GraphQL dan REST API memiliki selisih 0,6 detik dengan GraphQL yang lebih unggul. Dari segi efisiensi kuota data, dapat dilihat bahwa untuk data yang diterima, GraphQL lebih hemat sumber daya. Namun, pada bagian data yang dikirmkan, REST $A P I$ lebih unggul. Hal ini terjadi karena GraphQL mengirimkan data berupa query pada backend, sedangkan REST hanya mengirimkan endpoint apa yang dituju. Sehingga, REST menggunakan kuota data lebih sedikit dibandingkan dengan GraphQL. Namun, karena GraphQL mengirimkan query ke backend, maka GraphQL dapat menentukan data apasaja yang dibutuhkan oleh frontend. Sehingga, tidak terjadi kelebihan data dari jumlah data yang diperlukan. Hal inilah yang membuat GraphQL dapat menghemat kuota lebih baik dari REST ketika menerima data. 


\subsection{Hasil Load Testing Endpoint Halaman Edit Alumni}

Load testing pada endpoint halaman edit alumni dilakukan dengan menerapkan perlakuan yang sama pada load testing endpoint halaman list alumni dan halaman dashboard, dimana terdapat 50 user yang

akan melakukan request ke bagian backend. Setiap 1 user selesai mendapatkan respon dari backend, user tersebut akan segera melakukan request kembali. Hal ini akan terus berulang selama 1 menit.

Hasil yang diberikan oleh backend dengan REST menunjukkan bahwa terjadi 410 iterasi dengan jumlah request sebanyak 821 dan sebanyak 820 request berhasil direspon dengan sukses oleh backend. Sedangkan sisanya belum selesai direspon. Rata-rata kecepatan tiap iterasi adalah 6,8 detik dengan waktu terlama 8,7 detik dan waktu tercepat 1,8 detik.

Tabel 6 Hasil Load Testing Halaman Edit Alumni

\begin{tabular}{|l|c|c|c|c|}
\hline Metode & $\begin{array}{c}\text { Itera } \\
\text { si }\end{array}$ & $\begin{array}{c}\text { Kecepatan } \\
\text { rata- } \\
\text { rata/iterasi } \\
\text { (s) }\end{array}$ & $\begin{array}{c}\text { Total } \\
\text { data } \\
\text { dikirim } \\
(\mathbf{B})\end{array}$ & $\begin{array}{c}\text { Total } \\
\text { data } \\
\text { diterima } \\
(\mathbf{B})\end{array}$ \\
\hline $\begin{array}{l}\text { REST } \\
\text { API }\end{array}$ & 410 & 6,8 & 316560 & 1697150 \\
\hline $\begin{array}{l}\text { GraphQ } \\
\text { L }\end{array}$ & 415 & 6,8 & 344355 & 956845 \\
\hline
\end{tabular}

Sedangkan hasil yang diberikan oleh backend dengan GraphQL menunjukkan bahwa terjadi 415 iterasi dengan jumlah request 415 kali dan keseluruhannya mendapatkan respon sukses dari backend. Rata-rata durasi tiap iterasi adalah 6,8 detik dengan durasi terlama 8,5 detik dan durasi tersingkat adalah 0,5 detik.

Dari segi efisiensi kuota internet, sistem informasi dengan REST API menerima data sebesar 1697150 bytes dan mengirimkan data sebesar 316560 bytes. Pada sistem informasi dengan GraphQL, data yang diterima sebesar 956845 bytes dan data yang dikirimkan adalah 344355 bytes. Dari data tersebut, dapat dilihat bahwa GraphQL mampu menghemat penggunaan data yang diterima hampir 2 kali dari REST API.

Dari hasil uji coba di atas, dapat dilihat bahwa GraphQL dapat melakukan lebih banyak iterasi dibandingkan REST API yang artinya GraphQL dapat memanajemen request dari user dengan baik ketika terdapat banyak user yang mengakses data secara bersamaan. Untuk rata-rata kecepatan, kedua sistem backend memiliki rata-rata kecepatan yang sama. Dari segi efisiensi penggunaan kuota internet, GraphQL cukup unggul dibandingkan REST API.

\section{Kesimpulan}

Dari hasil load test sistem informasi yang sudah dibuat dengan Graph $Q L$ dan sistem informasi dengan REST API, dapat diambil kesimpulan bahwa, pada proses pemuatan halaman dengan data yang besar dan beragam, kasus under-fetching memberikan dampak pada durasi pemuatan halaman dan GraphQL mampu menangani pemuatan halaman lebih cepat. Pada kasus pemuatan halaman dengan data yang sederhana seperti pada halaman dashboard dan edit alumni, masalah under-fetching tidak memberikan dampak pada kecepatan muat halaman dan REST API masih lebih unggul.

Pada load test endpoint masing-masing backend, dapat diambil kesimpulan bahwa GraphQL mampu melayani lebih banyak user dibandingkan dengan REST API. Ini dibuktikan dengan lebih banyaknya iterasi yang terjadi pada hasil load test backend GraphQL dibandingkan dengan jumlah iterasi yang terjadi pada hasil load test backend dengan REST API. Kemudian, dari segi efisiensi penggunakan kuota internet, under-fetching memberikan masalah berupa pengiriman data pada beberapa respon. Sehingga, selain frontend harus mengirimkan token yang sama untuk divalidasi ke backend pada masing-masing endpoint, frontend juga akan mendapatkan data dari berbagai respon dengan berbagai header. Hal ini menyebabkan pembuangan kuota internet untuk mengirimkan dan mendapatkan data yang tidak perlu. GraphQL dapat mengatasi hal ini dengan menggunakan 1 endpoint dan mengirimkan query yang berisikan kebutuhan data apa saja yang kita inginkan untuk digunakan di frontend.

Dengan begitu, dapat diambil kesimpulan bahwa, untuk suatu halaman web yang sederhana dan dengan jumlah user yang tidak terlalu banyak dalam satu waktu akses, REST API masih dapat diandalkan sebagai metode distribusi data. Namun, ketika aplikasi atau website tersebut sudah mulai berkembang menjadi lebih kompleks dengan data yang cukup banyak dan dengan jumlah pengguna yang besar dalam satu waktu akses, serta berpeluang besar untuk terjadi under-fetching, GraphQL mulai diperlukan sebagai solusi dalam mengatasi underfetching dan mengoptimalkan kemampuan server dalam memberikan respon secara cepat kepada pengguna serta menghemat penggunaan kuota data internet oleh user. Sehingga, pengguna akan lebih nyaman dan merasa betah berada di halaman web yang dibuat. Karena pengguna merasa lebih nyaman, maka tentu hal ini akan dapat meningkatkan reputasi dari halaman web yang dikembangkan.

\section{Daftar Pustaka:}

Alex, B., \& Eve, P. (2017). Learning React Functional Web Development With React and Redux. 1005 Gravenstein Highway North, Sebastopol, CA 954721005 Gravenstein 
Highway North, Sebastopol, CA 95472: O'Reilly Media, Inc.

Biehl, M. (2015). API Architecture: The Big Picture for Building APIs.

Brito, G., \& Valente, M. T. (2020). REST vs GraphQL: A controlled experiment. Proceedings - IEEE 17th International Conference on Software Architecture, ICSA 2020, (Dcc), 81-91. https://doi.org/10.1109/ICSA47634.2020.0001 6

Brown, E. (2014). Web development with Node \& Express. In O'Reilly Media, Inc. (Vol. 1). 1005 Gravenstein Highway North, Sebastopol, CA 95472: O'Reilly Media, Inc.

Buna, S. (2021). GraphQL in Action. Shelter Island, NY 11964: Manning Publication Co.

Čechák, D. (2017). Using GraphQL for Content Delivery in Kentico Cloud. Is.Muni.Cz. Retrieved from https://is.muni.cz/th/qm0cs/thesis.pdf

Cederlund, M. (2016). Performance of frameworks for declarative data fetching : An evaluation of Falcor and Relay+GraphQL. (2016:92), 105.

Doglio, F. (2018). REST API Development with Node.js: Manage and Understand the Full Capabilities of Successful REST Development. Retrieved from https://isbnsearch.org/isbn/9781484237144

Eizinger, T. (2017). API Design in Distributed Systems: A Comparison between GraphQL and REST. 1-64. Retrieved from https://eizinger.io/assets/Master-Thesis.pdf

Hartig, O., \& Pérez, J. (2017). An initial analysis of facebook's GraphQL language. CEUR Workshop Proceedings, 1912.

Hartina, D. A., Lawi, A., \& Panggabean, B. L. E. (2018). Performance Analysis of GraphQL and RESTful in SIM LP2M of the Hasanuddin University. Proceedings - 2nd East Indonesia Conference on Computer and Information Technology: Internet of Things for Industry, EIConCIT 2018, 237-240. https://doi.org/10.1109/EIConCIT.2018.88785 24

Hillar, G. C. (2016). Building RESTful Python Web Services. Birmingham: Packt Publishing Ltd.

Jeon, D. C., Liuhaoyang, \& Hwang, H. (2019). Design of Hybrid Application Based on GraphQL for Efficient Query for PHR. ICTC 2019 - 10th International Conference on ICT Convergence: ICT Convergence Leading the Autonomous Future, 381-383. https://doi.org/10.1109/ICTC46691.2019.8940 003

Kniberg, H., \& Skarin, M. (2010). Kanban And Scrum Making The Most Of Both (1st ed.). C4Media Inc.

Lee, E., Kwon, K., \& Yun, J. (2020). Performance Measurement of GraphQL API in Home ESS
Data Server. International Conference on ICT Convergence, 2020-October, 1929-1931. https://doi.org/10.1109/ICTC49870.2020.9289 569

Mukhiya, S. K., Rabbiab, F., Punax, V. K. I., Rutle, A., \& Lamo, Y. (2019). A GraphQL approach to healthcare information exchange with $\mathrm{hl} 7$ fhir. Procedia Computer Science, 160, 338345. https://doi.org/10.1016/j.procs.2019.11.082

Porcello, E., \& Banks, A. (2018). Learning GraphQL. In O'Reilly Media, Inc.O'Reilly Media, Inc. (1st ed.). 1005 Gravenstein Highway North, Sebastopol, CA 95472: O'Reilly Media, Inc.

Sharma, S. (2021). Modern API Development with Spring and Spring Boot. Birmingham: Packt Publishing Ltd.

Vadlamani, L., Emdon, B., Arts, J., \& Baysal, O. (2021). Can GraphQL Replace REST? A Study of Their Efficiency and Viability. 10-17. https://doi.org/10.1109/SERIP52554.2021.00009

Vazquez-Ingelmo, A., Cruz-Benito, J., \& GarcíaPenalvo, F. J. (2017). Improving the OEEU's data-driven technological ecosystem's interoperability with GraphQL. ACM International Conference Proceeding Series, Part F1322. 
Volume 7, Edisi 4, Agustus 2021

$\mathbf{8 0} \mid \mathrm{H}$ a 1 a $\mathrm{m}$ a $\mathrm{n}$ 